\title{
Peningkatan Minat dan Hasil Belajar Biologi Materi Sistem Transportasi Manusia melalui Pembelajaran Role Playing Siswa Kelas VIII-H SMPN 5 Surakarta Semester I Tahun 2013/2014
}

\author{
Increasing Interest and the Learning Outcomes of Biologi Material \\ Circulatory System in Humans Through Learning Model Role Playing for \\ Students Level VIIIH SMPN 5 Surakarta at Semester 1 by \\ the Year of 2013/2014
}

\author{
BANATI RAHMAWATI \\ SMP Negeri 5 Surakarta \\ *email: mayesbanatierha@ymail.com
}

Manuscript received: 24 Oktober 2013 Revision accepted: 20 Januari 2014

\begin{abstract}
SMPN5 Surakarta has outstanding vision and cultured on faith and Piety.the subjects of biology in this Surakarta SMPN5 not as expected, on his way to the front of learning in general should be improved particularly in the teaching of science including biology science subjects. research that has been conducted on 32 students are $47.5 \%$ of students who pay attention to the lessons, $12.5 \%$ of students dreamy, sleepy students $7.5 \%, 12.5 \%$ of students do not focus on the subject and only $20 \%$ of students participate in learning. lack of student interest in the learning process led to the success of student learning achieved suboptimal anyway. Research conducted in the semester began in July to December 2013, with the implementation of measures in October to November 2013 in SMPN5 Surakarta with the subject viii h grade students who are 32 students. On the first cycle students learn in a large group of 8 students in one group, while in the second cycle students learn in small groups, namely 4 students in one group. Each stage of each cycle consisting of planning actions, implementation of action, observation and reflection action. data using quantitative descriptive analysis by comparing the initial conditions of mastery learning cycle 1 and cycle 2 . The results showed a significant increase in interest in learning from the initial condition is active only 8 students to 30 students are active, attentive and happy while learning. learning outcomes of students has increased from baseline to 1 cycle of $21 \%$. cycle 1 to cycle 2 increased $6 \%$. learning outcomes from baseline to 2 cycles increased $29 \%$ The results of these studies indicate that through role playing learning model can improve student interest and learning outcomes.
\end{abstract}

Keywords: interest, the learning outcomes, role playing

\section{LATAR BELAKANG}

SMP Negeri 5 Surakarta memiliki visi "BERPRESTASI DAN BERBUDAYA BERDASARKAN IMAN DAN TAQWA".Nilai mata pelajaran Biologi di SMP Negeri 5 Surakarta ini belum sesuai harapan, dalam perjalananya ke depan pembelajaran secara umum harus lebih ditingkatkan khususnya dalam pembelajaran Sains termasuk bidang studi sains Biologi. Semua itu tidak lepas dari peran guru yang sangat menentukan dalam pelaksanaan kegiatan proses belajar mengajar, guru bertanggung jawab mengembangkan intelektualisme siswa sehingga diperlukan upaya kualitas hasil belajar.

Kegiatan siswa di dalam proses belajar mengajar lebih banyak mendengarkan apa yang disampaikan oleh guru, keterlibatan siswa masih kurang dan belum menyeluruh serta hanya didominasi oleh siswa tertentu saja. Pembelajaran yang dilakukan masih berpusat pada guru. Akibatnya terlihat beberapa siswa yang bercanda, mengantuk dan melamun. Dari penelitian yang telah dilakukan terhadap 32 siswa, terdapat 47,5\% siswa yang memperhatikan pelajaran, 12,5\% siswa melamun, 7,5\% siswa mengantuk, $12,5 \%$ siswa tidak fokus pada pelajaran, dan hanya $20 \%$ siswa yang berpartisipasi dalam pembelajaran. Kurangnya minat siswa dalam proses pembelajaran menyebabkan keberhasilan belajar yang dicapai siswa kurang optimal pula. Oleh karena itu, diperlukan peningkatan keterlibatan siswa dalam pembelajaran meliputi keterlibatan fisik dan keterlibatan emosional.

Minat merupakan salah satu unsur pribadi yang dapat mempengaruhi pencapaian hasil belajar siswa dalam bidang studi. Minat belajar akan timbul pada diri siswa apabila pada dirinya terdapat sikap menaruh perhatian lebih terhadap pelajaran tanpa ada unsur paksaan. Adanya minat belajar yang optimal dapat mempengaruhi pencapaian hasil belajar yang optimal pula. Seorang siswa yang memiliki minat yang tinggi akan membuat siswa belajar dengan penuh keikhlasan dan kegemaran yang selanjutnya hasil belajar akan menjadi lebih baik, 
sebaliknya seorang siswa yang memiliki minat rendah hasil belajar yang dicapai akan rendah juga.

Berpijak pada kenyataan tersebut salah satu alternatif pemecahan masalah yang diajukan adalah dengan pengembangan potensi belajar biologi siswa melalui model pembelajaran yang dapat memacu siswa secara aktif dan terlibat sepenuhnya dalam proses pembelajaran. Di samping itu, dapat dikembangkan pula inovasi strategi pembelajaran PAIKEM (Pembelajaran Aktif, Inovatif, Kreatif, Efektif, dan Menyenangkan). Model pembelajaran yang dianggap akan sesuai dan dapat diterapkan dalam menunjang keberhasilan pembelajaran konsep sistem peredaran darah pada manusia ini salah satunya adalah model pembelajaran Role playing. Pusat dari Role playing adalah berinteraksi sesama, mereka melakukan peran terbuka dalam mempraktikan isi pelajaran yang baru, mereka diberi kesempatan seluasluasnya untuk memerankan sehingga menemukan kemungkinan masalah yang akan dihadap dalam pelaksanaan sesungguhnya.

Menurut Slameto (1991: 180) minat diartikan sebagai "Rasa lebih suka dan rasa keterikatan pada suatu hal atau aktivitas, tanpa ada yang menyuruh". Minat pada dasarnya adalah penerimaan akan sesuatu hubungan antar diri sendiri dengan sesuatu di luar diri. Semakin kuat atau dekat hubungan tersebut, semakin besar minatnya.

Djaali (2007: 122) menyatakan bahwa "Minat adalah perasaan ingin tahu, mempelajari, mengagumi atau memiliki sesuatu". Sedangkan menurut Slameto (1991: 57) bahwa "Minat adalah kecenderungan yang tetap untuk memperhatikan sesuatu dan mengenang beberapa kegiatan. Kegiatan yang diminati seseorang, diperhatikan terus menerus yang disertai dengan rasa senang”.

Minat tidak dibawa sejak lahir, melainkan sesuatu yang dapat disadari dan dikembangkan. Minat seseorang terhadap suatu hal dapat ditumbuhkan dengan dua cara yaitu berusaha untuk memperoleh informasi tentang hal tersebut dan melakukan aktivitas yang bekaitan dengan hal itu. Kedua cara tersebut sangat bertautan, hal ini dapat dipahami, karena untuk memperoleh informasi seseorang biasanya berusaha semaksimal mungkin untuk memperoleh info sebanyak-banyaknya.

Belajar adalah sebuah proses, dimana hasil dari proses belajar adalah perubahan tingkah laku, kecakapan dan berbagai sifat. Hasil dari proses belajar tersebut dapat dinilai melalui evaluasi. Menurut Nana Sudjana (1991: 22) "Hasil belajar adalah kemampuan-kemampuan yang dimiliki siswa setelah ia menerima pengalaman belajarnya." Hasil belajar siswa ini menampakkan diri pada perubahan tingkah laku, misalnya dari tidak mengetahui menjadi mengetahui (Masidjo, 1995: 92).

Role Playing dikembangkan oleh Shlomo dan Yael Sharan di Universitas Tel Aviv, merupakan perencanaan pengaturan kelas yang umum di mana para siswa bekerja dalam kelompok kecil menggunakan pertanyaan kooperatif, diskusi kelompok, serta perencanaan dan proyek kooperatif. Pada metode ini para siswa dibebaskan membentuk kelompoknya sendiri yang terdiri dari dua sampai enam orang anggota. Kelompok ini kemudian memilih topik-topik dari unit yang telah dipelajari oleh seluruh kelas, membagi topik-topik ini menjadi tugastugas pribadi, dan melakukan kegiatan yang diperlukan untuk mempersiapkan laporan kelompok. Setiap kelompok lalu mempresentasikan atau menampilkan hasil penemuan mereka di hadapan seluruh kelas.

Bermain peran adalah mendramatisasikan cara bertingkah laku orang-orang tertentu dalam posisi yang membedakan peranan masing-masing dalam suatu organisasi atau kelompok dimasyarakat (Hadari Nawawi, 1993:295). Jadi secara singkat metode bermain peran adalah cara atau jalan untuk mendramatisasikan cara bertingkah laku orang-orang tertentu didalam posisi yang membedakan peranan masing-masing.

Apabila ditinjau secara istilah, metode bermain peran adalah bentuk metode mengajar dengan mendramakan atau memerankan cara bertingkah laku dalam hubungan sosial, yang lebih menekankan pada kenyataan-kenyataan dimana murid diikutsertakan dalam memainkan peranan di dalam mendramakan masalah-masalah dalam hubungan sosial. Metode ini kadang-kadang disebut dramatisasi (Zuhairini, dkk., 1983: 101-102)

Banyak kelebihan yang dimiliki model pembelajaran role playing. Kelebihan-kelebihan tersebut di antaranya:

1. Menarik perhatian siswa karena masalah-masalah sosial berguna bagi mereka;

2. Bagi siswa; berperan seperti orang lain, ia dapat merasakan perasaan orang lain; mengakui pendapat orang lain itu; saling pengertian; tenggang rasa; toleransi;

3. Melatih siswa untuk mendesain penemuan;

4. Berpikir dan bertindak kreatif;

5. Memecahkan masalah yang dihadapi secara realistis karena siswa dapat menghayatinya;

6. Mengidentifikasi dan melakukan penyelidikan;

7. Menafsirkan dan mengevaluasi hasil pengamatan;

8. Merangsang perkembangan kemajuan berpikir siswa untuk menyelesaikan masalah yang dihadapi dengan tepat;

9. Dapat membuat pendidikan sekolah lebih relevan dengan kehidupan, khususnya dunia kerja (Djumingin, 2011: 175-176)..

10. Siswa bebas mengambil keputusan dan berekspresi secara utuh;

11. Dapat berkesan dengan kuat dan tahan lama dalam ingatan siswa. Disamping merupakan pengaman yang menyenangkan yang saling untuk dilupakan;

12. Sangat menarik bagi siswa, sehingga memungkinkan kelas menjadi dinamis dan penuh antusias;

Membangkitkan gairah dan semangat optimisme dalam diri siswa serta menumbuhkan rasa kebersamaan dan kesetiakawanan sosial yang tinggi (Santoso, 2011).

\section{METODE}

Penelitian ini merupakan penelitian tindakan kelas (Classroom Action Research). Jenis pemelitian ini termasuk penelitian kualitatif dengan tindakan partisipan 
karena peneliti terlibat langsung dari awal hingga akhir penelitian. Penelitian dilakukan 2 siklus dengan target capaian peningkatan hasil belajar sebnayak $25 \%$ dari kondisi awal. Siklus pertama pembelajaran dilaksanakan dalam kelompok besar dan siklus kedua dilaksanakan dalam kelompok kecil.

Subjek pada penelitian ini adalah siswa kelas VIII H di SMP Negeri 5 Surakarta semester 1 tahun pelajaran 2013/2014 yang berjumlah 32 siswa. Objek penelitian ini adalah minat dan hasil belajar biologi siswa kelas VIII $\mathrm{H}$ di SMP Negeri 5 Surakarta semester 1 tahun pelajaran 2013/2014 materi Sistem peredaran darah manusia melalui model pembelajaran Role playing.

Data pada penelitian ini berupa data primer yaitu : minat siswa kondisi awal, hasil belajar siswa kondisi awal, minat siswa siklus 1 , hasil belajar siklus 1 , minat siswa siklus 2, hasil belajar siswa siklus 2. Sedangkan data sekunder merupakan data penunjang sebagai pelengkap berupa:

1. Daftar nama siswa yang tidak berperan aktif saat pembelajaran berlangsung hasil observasi teman sejawat.

2. Data hasil observasi teman sejawat terhadap guru dan siswa saat pembelajaran.

3. Sumber data diatas diperoleh dari subjek penelitian yaitu siswa kelas VIII H di SMP Negeri 5 Surakarta semester 1 tahun pelajaran 2013/2014.

Analisis Data minat Belajar Siswa terdapat 3 data minat belajar siswa yaitu minat belajar siswa kondisi awal, siklus 1dan siklus 2. Data-data tersebut dianalisis menggunakan teknik deskriptif komparatif dilanjutkan refleksi. Deskriptif komparatif yaitu membandingkan secara deskripsi antara data minat belajar kondisi awal siswa dengan siklus 1 . Minat belajar siswa siklus 1 dengan siklus 2, dan minat belajar kondisi awal siswa dengan siklus 2 atau kondisi akhir.

Analisis Data Hasil Belajar Siswa terdapat 3 data hasil belajar siswa yaitu hasil belajar kondisi awal, siklus 1 dan siklus 2. Data-data tersebut dianalisis menggunakan teknik deskriptif komparatif dilanjutkan refleksi. Deskriptif komparatif yaitu membandingkan secara deskripsi antara data hasil belajar kondisi awal siswa dengan siklus 1 . Hasil belajar siswa siklus 1 dengan siklus 2, dan Hasil belajar kondisi awal siswa dengan siklus 2 atau kondisi akhir.

\section{HASIL DAN PEMBAHASAN}

Penelitian ini dilaksanakan dalam 2 siklus pembelajaran dengan model pembelajaran role playing. Pada setiap siklus yang diterapkan pada proses pembelajan menunjukkan hasil yang berbeda.

Hasil penelitian pada pra tindakan, siklus 1 , dan siklus 2 dapat dilihat pada tabel 1 berikut:

Tabel 1. Peningkatan Minat Belajar Pada Kondisi Awal, Siklus 1 dan Siklus 2

\begin{tabular}{|c|c|c|}
\hline $\begin{array}{l}\text { KONDISI PRA- } \\
\text { SIKLUS }\end{array}$ & SIKLUS I & SIKLUS II \\
\hline $\begin{array}{l}\text { Sebanyak } 14 \text { siswa } \\
\text { tidak } \\
\text { memperhatikan } \\
(43,8 \%) \\
4 \text { siswa melamun } \\
(12,5 \%) \\
2 \text { siswa } \\
\text { menggantuk ( } 6,3 \\
\%) \\
4 \text { siswa tidak fokus } \\
(12,5 \%) \text {. } \\
\text { Hanya } 8 \text { siswa } \\
\text { yang aktif }(25 \%)\end{array}$ & $\begin{array}{l}\text { Dengan } \\
\text { menggunakan } \\
\text { metode role } \\
\text { playing hanya } \\
\text { ditemukan sekitar } \\
8 \text { siswa yang } \\
\text { kurang } \\
\text { memperhatikan } \\
\text { saat pembelajaran } \\
\text { berlangsung atau } \\
\text { sekitar } 25 \%\end{array}$ & $\begin{array}{l}\text { Dengan } \\
\text { menggunakan } \\
\text { metode role } \\
\text { playing pada } \\
\text { siklus II hanya } \\
\text { ditemukan sekitar } \\
2 \text { siswa yang } \\
\text { kurang } \\
\text { memperhatikan } \\
\text { saat pembelajaran } \\
\text { berlangsung, } \\
\text { sedangkan hampir } \\
\text { seluruh siswa } \\
\text { serius dalam } \\
\text { pembelajaran atau } \\
\text { sekitar 93,7 \% } \\
\text { siswa aktif dalam } \\
\text { proses } \\
\text { pembelajaran }\end{array}$ \\
\hline
\end{tabular}

Dari tabel 1 terjadi peningkatan minat belajar siswa, hal ini dapat terlihat adanya peningkatan siswa yang mulai memperhatikan pelajaran dan perasaan senang terhadap materi ini mulai terlihat terbukti hampir seluruh siswa aktif saat pelajaran berlangsung.

Tabel 2. Hasil belajar dari kondisi awal sampai tindakan siklus.

\begin{tabular}{lccc}
\hline \multicolumn{1}{c}{ HASIL TES } & KONDISI & \multicolumn{2}{c}{ TINDAKAN } \\
& AWAL & SIKLUS I & SIKLUS II \\
\hline Nilai terendah & 40 & 50 & 58 \\
Nilai rata-rata & 73 & 76 & 78 \\
Nilai tertinggi & 91 & 93 & 97 \\
Siswa & 19 & 26 & 28 \\
melampaui & 13 & 6 & 4 \\
KKM & $59 \%$ & $82 \%$ & $88 \%$ \\
Siswa dibawah & & & \\
KKM & & & \\
Persentasi tuntas & & & \\
klasikal & & & \\
\hline
\end{tabular}

Keberhasilan secara afektif diperkuat pula dari penilaian proses pembelajaran pada saat dilaksanakan observasi selama pembelajaran berlangsung. Pada Siklus I taraf ketuntasan pembelajaran termasuk dalam kriteria baik, karena terjadi peningkatan $23 \%$. Hal ini Sedangkan pada siklus II mengalami peningkatan $29 \%$, Kedua hasil tersebut merupakan kriteria taraf keberhasilan yang baik.

Berikut adalah diagram batang dari hasil penilaian proses pembelajaran menggunakan motode role playing 


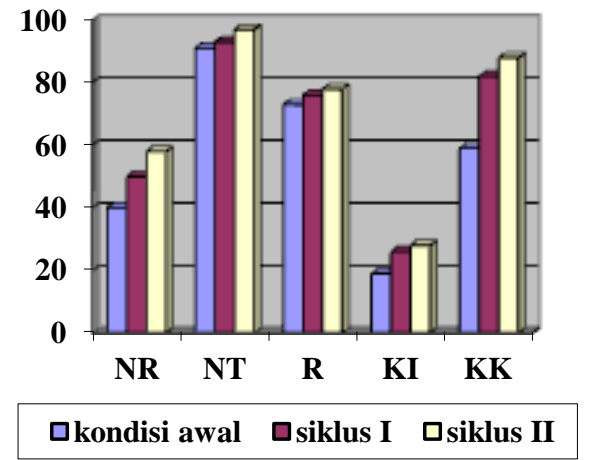

Keterangan : NR: Nilai Terendah, $\quad$ NT: Nilai Tertinggi, $\quad$ R: Rata - rata, KI: Ketuntasan Individu, KK: Ketuntasan Klasikal

Gambar 1. Peningkatan Hasil Belajar Siswa

Dari gambar 1 diperoleh gambaran bahwa setelah dilakukan tindakan didalam proses belajar mengajardengan menggunakan metode role playing sangat membantu siswa dalam menguasai materi pembelajaran sehingga hasil belajar siswa secara individu dan klasikal menjadi lebih baik.

Guru dan observer mengalami kesulitan untuk memperoleh data yang berarti baik data minat maupun kognitif. Kesulitan ini dimungkinkan terjadi karena beberapa sebab berikut

1. Guru belum berpengalaman menerapkan metode role playing di dalam kelas, sehingga kesulitan dalam memprediksikan hal-hal ya ng mungkin dapat terjadi di luar dugaan.

2. Siswa belum terbiasa menerapkan metode role playing sehingga tidak siap dan belum mengerti sepenuhnya apa yang harus dilaksanakan. Tampak dalam pengamatan, tidak seluruh siswa mampu melaksanakan apa yang diinstruksikan guru.

3. Siswa masih kurang keberanian dalam mengemukakan penilaian, pendapat dan komentarnya

4. Suasana senang dalam belajar sudah tampak, meskipun masih ada siswa yang terlihat kurang bersemangat.

Menurut Ahmadi dkk (2011: 35) menyatakan bahwa melalui permainan peran,siswa dapat meningkatkan kemampuan mengenal perasaan dirinya dan perasaan orang lain. Mereka memperoleh cara berperilaku baru untuk mengatasi situasi masalahnya seperti dalam permainan perannya dan dapat meningkatkanketerampilan memecahkan masalah. Zaini dkk (2008:99) juga mengatakan bahwa role play dapat membuktikan diri sebagai suatu media pendidikan yang sangat ampuh, di mana saja terdapat peran - peran yang dapat didefinisikan dengan jelas, yang memiliki interaksi yang mungkin dieksplorasi dalam keadaan yang bersifat simulasi (skenario).

Belajar adalah suatu proses usaha yang dilakukan seseorang untuk memperoleh suatu proses perubahan tingkah laku yang baru secra keseluruhan, sebagai hasil pengalamannya sendiri dalam interaksi dengan lingkungannya (Slameto, 2003). Strategi pembelajaran adalah cara mengajar yang dapat digunakan untuk mengajarkan tiap bahan pelajaran (Purwoto, 1998). Menurut Hasibuan (1992), mengatakan bahwa strategi pembelajaran adalah alat yang merupakan bagian dari perangkat alat dan cara dalam pelaksanaan suatu strategi pembelajaran untuk mencapai tujuan belajar. Strategi merupakan suatu rencana tentang cara-cara penggunaan potensi dan sarana yang ada untuk meningkatkan efektifitas dan efisiensi (dalam hal ini adalah pengajaran) (Slameto, 2003).

Istilah model pembelajaran mempunyai empat ciri khusus yang tidak dimiliki oleh strategi atau prosedur tertentu. Hal ini dinyatakan dalam Depdiknas (2004:1).Ciri-ciri tersebut adalah (1) rasional teoritik yang logis yang disusun oleh para pencipta atau pengembangnya; (2) landasan pemikiran tentang apa dan bagaimana siswa belajar (tujuan pembelajaran yang akan dicapai); (3) tingkah laku mengajar yang diperlukan agar model tersebut dapat dilaksanakan dengan berhasil; dan (4) lingkungan belajar yang diperlukan agar tujuan pembelajaran itu dapat tercapai.

Pada setiap model pembelajaran dikenal adanya sintaks atau pola urutan yang menggambarkan keseluruhan alur langkah yang pada umumnya diikuti oleh serangkaian kegiatan pembelajaran. Masih dalam Depdiknas (2004:2) dikemukakan bahwa, "Sintaks pembelajarn menunjukkan dengan jelas kegiatan-kegiatan apa yang perlu dilakukan guru atau siswa,urutan kegiatankegiatan tersebut,dan tugas-tugas khusus yang perlu dilakukan oleh siswa".

Berdasarkan pendapat-pendapat di atas dapat disimpulkan bahwa, dalam menyajikan materi pelajaran guru dapat memilih strategi pembelajaran apapun. Diantaranya dapat menentukan jenis model pembelajaran yang telah disusun secara sistematik untuk mengatur efektifitas dan efisiensi dalam mencapai tujuan yang ditetapkan.

Model pembelajaran role playing yang diterapkan oleh guru dalam penelitian ini, dipilih dengan anggapan bahwa siswa kelas VIII $\mathrm{H}$ telah memiliki potensi yang aktif, tetapi belum terkelola dengan baik. Perilaku siswa selama proses pembelajaran belum positif, sehingga suasana kelas sangat tidak kondusif untuk berlangsungnya proses pembelajaran yang efektif dan efisien guna mencapai tujuan pembelajaran. Kemampuan akademik siswa kelas VIII $\mathrm{H}$ dalam kategori rendah hingga sedang. Hanya beberapa siswa memiliki kemampuan akademik rata-rata atas.

Disisi lain siswa kelas VIII-H merupakan siswa yang cukup berpotensi untuk dapat belajar aktif, misalnya tingkat keberanian bicara yang tinggi, beberapa siswa bahkan sering memiliki inisiatif yang baik serta tidak takut salah dalam menjawab soal.. Potensi keaktifan ini terbukti saat guru masuk kekelas VIII-H, guru harus menunggu beberapa saat untuk mengajar karena 
menunggu siswa tenang. Sehingga apabila potensi yang terpendam ini tidak dikelola dengan baik atau diarahkan ke hal yang positif, maka yang terjadi adalah bahwa mereka sering berbincang-bincang dan bergurau dengan temannya saat proses belajar mengajar berlangsung.

Gambaran mengenai perilaku siswa yang senang berbicara dengan teman semejanya saat pelajaran dimulai dan beberapa siswa yang sering meminta ijin ke kamar mandi merupakan indikasi adanya kejenuhan yang mereka rasakan. Kejenuhan dalam belajar itu berusaha mereka atasi dengan mencari suasana berbeda di luar kelas. Hal ini sebetulnya dapat dijadikan bahan koreksi bagi guru untuk mempelajari penyebab kejenuhan tersebut, sehingga guru dapat mengambil langkah bijaksana dan solutif. Akibat secara langsung yang terjadi adalah hasil belajar siswa cenderung rendah.

Pemilihan Motode Pembelajaran role playing ini melibatkan siswa belajar aktif (Carta, 1991) di dalam kelas dengan memberdayakan potensi yang dimilikinya. Tuntutan peran menjadi sesuai tuntutan mampu mengarahkan untuk menemukan ide-ide pokok materi kemudian mengkomunikasikannya kepada teman sekelompoknya dengan bahasa yang lebih mudah dipahami. Kemampuan menyampaikan gagasan untuk menyusun skenario pembelajaran sesuai materi yang dipelajari juga turut meningkatkan keterampilan dan rasa percaya diri (Fulk \& King, 2001) serta adanya perhatian terhadap pelajaran yang terus-menerus selama proses pembelajaran berlangsung.

Dari hasil kajian teori yang dipaparkan berguna untuk mendukung dan mendasari dalam mengatasi masalah yang diajukan oleh peneliti sehingga dalam menentukan pokok masalah yang akan dilakukan tindakan berdasarkan pedoman kebenaran pemikiran yang bersifat teoritis.

Setelah melakukan tindakan didapat data empiris yang selanjutnya diolah, dianalisis dan disimpulkan sehingga diperoleh kebenaran empiris yang didukung dengan kebenaran teoritis, terjawablah hipotesis yang diajukan bahwa secara teoritis dan empirik adalah benar bahwa dengan mengunakan metode pembelajaran role playing dapat meningkatkan minat belajar siswa dan hasil belajar biologi tentang sistem transportasi pada manusia bagi siswa kelas VIII H SMP Negeri 5 Surakarta semester ganjil tahun pelajaran $2013-2014$.

\section{KESIMPULAN}

Melalui model pembelajaran Role playing dapat meningkatkan minat belajar biologi sebesar 68,7 \% bagi siswa kelas VIIIH SMP Negeri 5 Surakarta pada semester II tahun 2013/2014.

Melalui model pembelajaran Role playing dapat meningkatkan hasil belajar biologi materi sistem peredaran darah pada manusia bagi siswa kelas VIIIH SMP Negeri 5 Surakarta pada semester II tahun 2013/2014 dengan peningkatan ketuntasan belajar secara klasikal dari:

1. Kondisi awal ke tindakan siklus I dengan peningkatan $23 \%$
2. Tindakan siklus I ke siklus II dengan peningkatan $6 \%$

3. Kondisi awal ke tindakan siklus 2 denagn peningkatan $29 \%$

Melalui model pembelajaran Role playing dapat meningkatkan minat dan hasil hasil belajar biologi materi sistem peredaran darah pada manusia bagi siswa kelas VIIIH SMP Negeri 5 Surakarta pada semester II tahun $2013 / 2014$

\section{DAFTAR PUSTAKA}

Carta, J.J. (1991). Education for young chilldrenin inner-city Classrooms. American Behavioral Scientist.

Depdiknas. (2004). Peningkatan Kualitas Pembelajaran. Jakarta: Direktorat Jenderal Pendidikan Tinggi Direktorat Pembinaan Pendidikan Tenag Kependidikan.

Fulk, B.M., \& King, K. (2001). Classwide Peer Tutorial at Work. Exceptional Children.

Hariani, D. 2012. Pengaruh Penerapan Model Pembelajaran Role Playing Terhadap Minat Belajar Siswa Kelas III Mata Pelajaran IPA SDN Sidorejo Lor 06 Salatiga Semester II Tahun Pelajaran 2011/2012. Http://repositori.library.uksw.edu/handle/123456789/937.

Hasibuan, J.J. (1992). Proses Belajar Mengajar. Bandung: Remaja Rosdakarya.

Sudjana, N. (1996). Cara Belajar Siswa Aktif dalam Proses Belajar Mengajar. Bandung : Sinar Baru Algesindo.

Purwadarminta, W.J.S. (1993). Kamus Umum Bahasa Indonesia. Jakarta : Balai Pustaka.

Lestari, Puji. (2013). Pengaruh Penggunaan Model Pembelajaran Rple Playing Terhadap Hasil Belajar Ekonomi Siswa Kelas XI IPS SMA Negeri 1 Muaro Jambi. Artikel ilmiah, UNJA.

Santoso, R. B. E. (2011). Model Pembelajaran Role Playing, (Online), http://ras-eko.blogspot.com/2011/05/modelpembelajarn-role-playing.html, diakses 25 Desember 2012

Sudjana, S. (2001). Metode dan Amplikasi Teknik Pembelajaran Partisipatif. Bandung. Falah Production.

Arikunto, S., Suhardjono, \& Supardi. (2008). Penelitian Tindakan Kelas. Jakarta: Bumi Aksara.

Sutopo, H.B. (2002). Metodologi Penelitian Kualitatif. Surakarta: UNS Press.

Purwoto. (1998). Strategi Belajar Mengajar Biologi. Surakarta: UNS Press.

Roestiyah, N.K. (1991). Strategi Belajar Mengajar. Jakarta: Erlangga.

Slameto. (1991). Proses Belajar Mengajar dalam Sistem Kredit Semester (SKS). Jakarta: Bumi Aksara.

Slameto. (2003). Belajar dan Faktor-faktor yang Mempengaruhinya. Jakarta: Rineka Cipta. 